\title{
The role of the audit of investment projects for the digital economy
}

\author{
Bakhyt Sultanova ${ }^{1, *}$, Madi Baidauletov ${ }^{1}$, Almyra Arystambayeva ${ }^{1}$, Dilyara Espaeva $^{1}$ \\ ${ }^{1}$ Al-Farabi Kazakh National University, al-Farabi Ave. 71, 050040 Almaty, Kazakhstan
}

\begin{abstract}
In this article, a new stage of industrial-innovative modernization of the economy of Kazakhstan is considered in the framework of the State program of industrial-innovative development of the Republic of Kazakhstan for 2020-2025. The main goal of the work is to justify the need to develop an audit of investment projects as an effective way to solve the key problem of the lack of control over the implementation of investment projects dedicated to the development of the digital economy, which leads to a decrease in the economic development of Kazakhstani organizations and the abuse of investment resources. The theoretical basis of the study is the work of well-known domestic economists and specialists in the field of accounting and auditing, as well as foreign experts. In the course of the research work, the legislative acts of the Republic of Kazakhstan, various regulatory legal acts were also considered. In the course of the work, such general scientific methods as analysis, generalization, and abstraction were used. In conclusion, the author made the following conclusions: it is necessary to develop new measures to solve the key tasks of evaluating the results of investment projects, the use of audit is the most effective way to prevent the negative consequences of the organization's investment activity and inform users about its financial situation.
\end{abstract}

\section{Introduction}

In accordance with Article 284 of Chapter 25 of the Entrepreneurial Code of the Republic of Kazakhstan of October 29, 2015, an investment project is a set of measures involving investments in the creation of new, expansion and renovation of existing industries, including production created, expanded and updated during the implementation of a public-private project. partnerships, including a concession project.

Investment projects occupy a special place in the implementation of the State program of industrial - innovative development of the Republic of Kazakhstan for 2020-2025. This program represents the main tasks and ways to achieve them at the new stage of industrial innovative modernization of the economy of Kazakhstan. Within the framework of the program, the imperfection of the system of control over the implementation of innovative projects was referred to the key problems of increasing the industrial and innovative potential of the Republic.

\footnotetext{
* Corresponding author: bbakut_sul@mail.ru
} 
The digital economy of Kazakhstan is also undergoing changes leading to development. But this area needs an infusion of investment, especially with the support of the state. The digital economy is associated with the ICT process. In fact, it has been the ICT [1]. However, this process needs to be monitored.

This problem can be solved through an audit of investment projects. At present, in Kazakhstan, audit organizations mainly carry out an audit of financial statements based on IFRS standards, as well as form audit opinions on taxes. At the same time, these types of audit services are in demand with the obligatory audit of large Kazakhstan enterprises, which have sufficient funds to pay for annual audits. In such conditions, an audit of investment projects in Kazakhstan does not receive its development, despite the fact that its implementation would significantly reduce the costs of organizations to evaluate the prospects of investment projects and would allow timely identification of deficiencies, violations and theft of financial resources during their implementation.

The study of the process of organizing an audit of investment projects allows to highlight the following advantages of this type of audit for commercial organizations:

- checking the correctness of accounting for the initial recognition of investments;

- control over the evaluation of investments after initial recognition when they are registered;

- checking the correctness of accounting for investment operations in investment projects;

- assessment of the completeness and accuracy of the reflection of investment operations in the financial statements of the entity being audited;

- control of the correctness of the inventory of investments and reflection in the accounting of its results;

- verification of compliance with tax laws on investment operations

- reduction of time for processing and monitoring the results of investment projects [2].

\section{Audit of investment projects for the digital economy}

The process of control of investment projects in the Republic of Kazakhstan is partially regulated by the adoption of the Law of the Republic of Kazakhstan dated November 12, 2015 No. 392-V “On State Audit and Financial Control”. Therefore, the costs associated with the rise in the cost of budget investment projects are checked by the authorized body for internal audit, namely the Ministry of Finance of the Republic of Kazakhstan.

However, this measure seems to be insufficient due to the fact that Kazakhstani non-state companies cannot use the services of state auditors when evaluating their own investment projects. If we consider the structure of investment projects by source of financing, then most of them will be invested on the basis of organizations' own funds [3]. The structure of investment in fixed assets is presented in Figure 1.

The control process should include both budget investment projects, and investment projects of private companies, implemented by them at their own expense, and investment projects with the attraction of foreign capital.

Increasing the interest of domestic companies in the audit of investment projects can be achieved by informing about the benefits of this type of audit. One of such advantages is the possibility of using the process approach, in particular, when auditing investment projects [4]. The accounting information systems' development experience proves that the top priorities of the company's business include the efficiency of collection, registration and further processing of accounting information [5]. The audit of investment projects is the verification of the compliance of an investment project with legal requirements [6]. In the course of the process approach in the audit of investment projects, the compliance with these 
requirements, the requirements of international standards and the effectiveness of the developed design estimates and other project documents [7] are assessed.

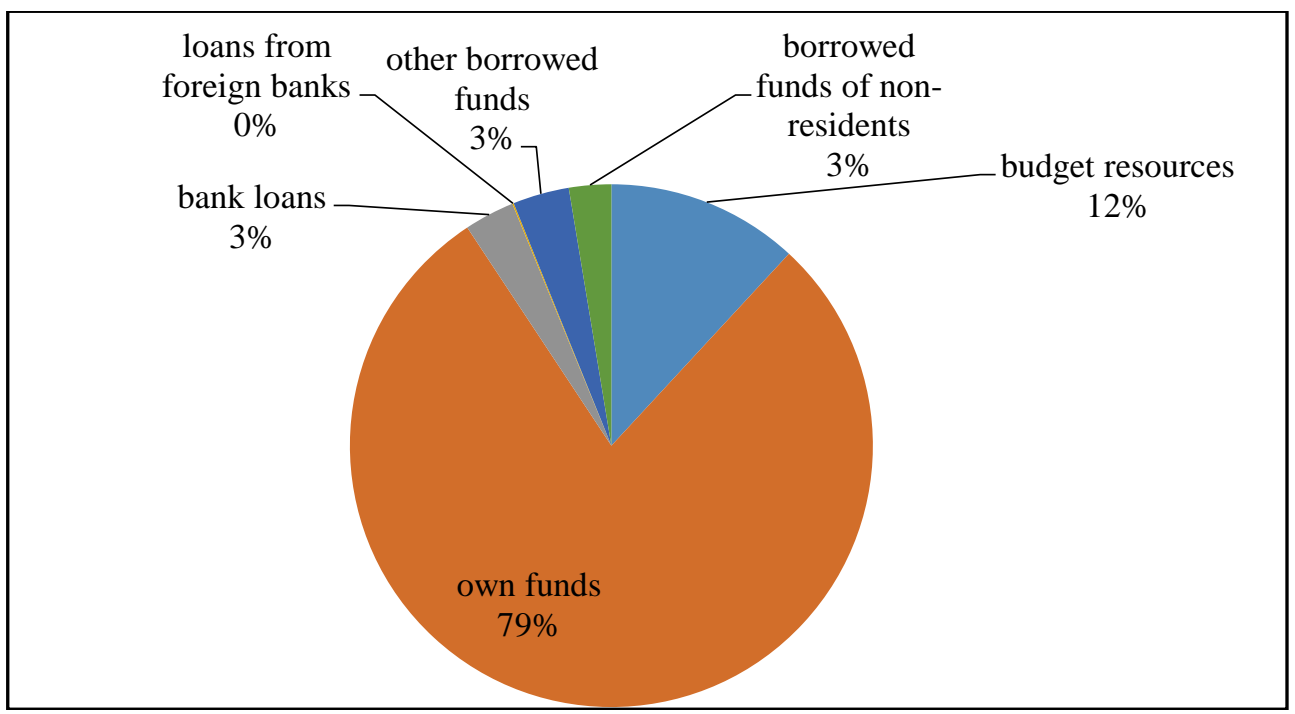

Fig. 1. The structure of investment in fixed assets in the Republic of Kazakhstan for January-December 2019 (Committee on Statistics of the Ministry of National Economy of the Republic of Kazakhstan).

The investment project itself is considered as a process of continuous interaction of investors with government agencies and private companies. When auditing investment projects, the auditor is guided by the type of investment project, determines the scope of the audit, draws up a plan and audit program. In Kazakhstan legislation, three types of investment projects can be distinguished, the main differences of which are presented in the form of Table 1.

Table 1. Types of investment projects.

\begin{tabular}{|c|c|c|c|}
\hline Project name & Investment project & $\begin{array}{c}\text { Investment priority } \\
\text { project }\end{array}$ & $\begin{array}{c}\text { Investment strategic } \\
\text { project }\end{array}$ \\
\hline 1.Description & $\begin{array}{l}\text { Investing in various } \\
\text { types of industries }\end{array}$ & $\begin{array}{l}\text { Investing in priority } \\
\text { activities according to } \\
\text { the list of the } \\
\text { Government of the } \\
\text { Republic of } \\
\text { Kazakhstan }\end{array}$ & $\begin{array}{l}\text { Investing in sectors } \\
\text { of strategic influence } \\
\text { on the economic } \\
\text { development of } \\
\text { Kazakhstan }\end{array}$ \\
\hline $\begin{array}{l}\text { 2. The size of the } \\
\text { investment }\end{array}$ & - & $\begin{array}{l}\text { - not less than } \\
2,000,000 \mathrm{MCI}\end{array}$ & - \\
\hline $\begin{array}{l}\text { 3. Types of } \\
\text { investment } \\
\text { preferences }\end{array}$ & $\begin{array}{l}\text { 1) exemption from } \\
\text { customs duties and } \\
\text { import VAT; } \\
\text { 2) state natural grants }\end{array}$ & $\begin{array}{l}\text { 1) tax preferences; } \\
\text { 2) investment subsidy }\end{array}$ & 1) tax preferences \\
\hline $\begin{array}{l}\text { 4. Types of tax } \\
\text { preferences VAT } \\
\text { exemption on imports } \\
\text { of raw materials and } \\
\text { (or) materials in the } \\
\text { framework of the } \\
\text { investment contract }\end{array}$ & $\begin{array}{l}\text {-Calculation at the } \\
\text { rate of } 0 \text { land tax and } \\
\text { property tax } \\
\text { - CIT sum is reduced } \\
\text { by } 100 \text { percent; }\end{array}$ & $\begin{array}{l}\text { CNP amount is } \\
\text { reduced by } 100 \\
\text { percent; }\end{array}$ & $\begin{array}{l}\text { - calculation at the } \\
\text { rate of } 0 \text { land tax and } \\
\text { property tax }\end{array}$ \\
\hline
\end{tabular}


Depending on the type of investment project, the auditor includes in the audit program documents confirming the investor's compliance with the conditions under which investment preferences are granted. Audit of investment projects solves the following tasks:

- verification of accounting for initial recognition of investments;

- the distinction in accounting for investments in investment projects according to the relevant criteria of their classification for long-term and short-term;

- control over the evaluation of investments after initial recognition when registering them;

- checking the correctness of accounting for investment operations in investment projects;

- system control of the state of synthetic and analytical accounting of investments;

- assessment of the completeness and correctness of the reflection of the investment operations of the financial statements of the entity being audited;

- control of the correctness of the inventory of investments and reflection in the accounting of its results;

- verification of compliance with tax legislation on investment operations [8].

Richardson examines the cash flow. It is clear that there is no doubt that it will help you. Further tests of firms are associated with the cash flow. The evidence suggests that there are certain governance structures, shareholders, appear to mitigate over-investment [9]. At the present stage of the formation of the world economy, the task of a commercial organization implementing investment projects is to identify ways to improve the audit of investment projects, since the assessment of investment attractiveness will be the initial stage in the complex process of forecasting activities for certain periods. The use of an audit of investment projects is a solution to the problem of assessing the investment attractiveness of a commercial organization in the medium and long term, confirming the accuracy of the formation and analysis of financial statements, which influences the development of enterprise development plans and, accordingly, management decisions [10].

The presence of an audit report containing positive conclusions about the correctness of the preparation and preparation of forward-looking financial statements is a positive factor influencing the investment attractiveness of an economic entity [11]. There are four possible categories of audit opinions (types of audit reports):

1. Unconditional conclusion (clean opinion) means that the auditor fully and unconditionally confirms financial statements. In the case of an audit of investment projects in the preparation of this type of report, the auditor agrees with the assessment of the company's investment resources and the results of the investment project.

2. The conclusion with reservation or conditionally positive (subject to opinion) is given in the case when the auditor confirms the financial statements with a certain degree of uncertainty that cannot be measured adequately. For example, it may be information relating to the amount of reserves, the amount of reserves to cover losses or other indicators, the value of which may vary depending on the method used in their assessment. When auditing investment projects, a conditionally positive audit report is compiled when there is a financial investment measured using the amortized cost method (that is, not measured at fair (market) value).

3. The conclusion with the reservation "with the exception of" (an except for opinion) means that the auditor was unable to verify some of the company's operations due to limitations imposed by its managers, or other reasons beyond the control of the auditor. The conclusion with a reservation in the audit of investment projects is given by the auditor with a lack of information on the evaluation of the results of the investment activities of the organization.

4. The disclaimer of opinion (opinion) is a statement by the auditor expressing a refusal 
to give any opinion regarding the financial condition of the company. Refusals to evaluate are rare in practice are quite rare, since they mean both the complete absence or refusal of management to provide information or affiliated relations with an auditor (audit organization) [12].

Auditors in commercial companies face certain problems in monitoring and evaluating the effectiveness of investment projects caused by important features of the Kazakhstan economy. These include:

- relatively high growth rates of prices, variable in time and different in types of products and resources, which do not coincide with the dynamics of exchange rates;

- a significant discrepancy between bank interest rates on loans and deposits;

- relatively high price of money, temporal, different for Kazakhstan and foreign project participants, causing a large variation and dynamic individual discount rates;

- a significant amount of construction in progress, unused production capacity and fixed assets that can be effectively used if there are additional investments;

- lack of established markets, especially securities market and real estate, and as a result - significant differences between the exchange and market value of securities, between ba lans, appraisal (given by independent appraisers) and the market value of the property;

- disruption of the natural connection for the market system between financial and real investments;

- significant uncertainty of the initial information for evaluating investment projects and high risk (including political) associated with their implementation;

- complexity and instability of the tax system;

- $\quad$ specific role of the state in the economy [13].

\section{Results and Discussion}

To solve these problems, the author suggests measures for evaluating investment projects c, which include:

1) The auditor needs to evaluate the following types of economic efficiency of investment projects (investment projects of economic efficiency):

- $\quad$ project efficiency as a whole;

- $\quad$ participation efficiency in a project (investment efficiency for project participants, equity effectiveness).

The project efficiency as a whole is subdivided on social (socio-economic) and commercial. The indicators of the social efficiency of the project (social efficiency) take into account the implications of the cost measurement of the investment Ion project for the considered public system, including costs and results in related areas, assuming that all the results of an investment project are used by this public system and all resources necessary for the project are produced at the expense of its resources. Indicators of the commercial efficiency of the project as a whole (commercial efficiency) take into account the financial implications of its implementation for the commercial structure that implements it and are determined on the assumption that all costs necessary for the implementation of the project. They are produced at the expense of its funds. The effectiveness of participation in a project (project participation efficiency) is determined in relation to various types of participants.

Accordingly, the calculations can be assessed:

- effectiveness of participation of enterprises in the project implementation;

- project efficiency for shareholders of joint-stock companies — participants of an investment project;

- efficiency (investments) for structures of a higher level in relation to enterprises project participants (national economy, regions, industries). Performance indicators (investments) for individual project participants (separate project participants efficiency) take 
into account the related consequences of the project (including the required costs, exchange rates and income received by the participant) and use a real scheme of its financing [14].

Concentrating on a certain kind of efficiency will allow the auditor to reduce the impact of variable cash value for Kazakhstan and foreign participants of the investment project, reduce the time spent on planning and development of working papers, as well as auditing procedures.

2) In the financial and investment cycle, the following responsibilities should be divided:

- $\quad$ investment and Lending Permit;

- $\quad$ investment Storage;

- $\quad$ investment Accounting;

- periodic Reconciliations.

3) To solve the significant uncertainty of the initial information to evaluate investment projects and high risk implementation, the auditor should focus on the following types of documents in order to obtain audit evidence: cash flow forecasts; budget of investment resources; treaties and agreements; register of shareholders and register of share certificates; bonds and notes in circulation; joint venture and partnership agreements; investment certificates; documents of registration of intangible assets, such as patents and trademarks; Protocols of the board of directors authorizing activities under an investment project, etc.

4) The problem of a significant difference between the exchange rate and market value of securities, between the book, appraisal and market value of a property can be solved by using the basic principles of audit control of investment projects:

- appropriate segregation of duties;

- $\quad$ appropriate level of corporate governance (i.e., knowledge, independence and involvement of the board of directors);

- $\quad$ use of third party services to complete the operation with investment recourses.

5) The complexity and instability of the tax system and accounting for the specific role of government in the economy is solved by the auditor during the audit of the relevant areas of monitoring of investment projects:

considered investment and financial transactions are real and have the appropriate documentation;

- all investment and financial transactions taken into account;

- $\quad$ permission obtained for all investment and financial transactions;

- $\quad$ investment and financial transactions are exactly completed and calculated;

- $\quad$ investment and financial transactions are properly classified;

- $\quad$ accounting for investment and financial transactions is carried out according to legal requirements;

- investment and financial transactions were taken into account in the relevant period [15].

6) Problems reflecting and confirming the reliability of high price growth rates, discrepancies between bank interest rates on loans and deposits, and the need for additional investments in fixed assets can be disclosed by the auditor when preparation of projected financial statements. The forward-looking income statement, the forecast balance, the forward-looking statement on cash flows, determine the forward-looking financial statements, which reflect the expected financial results of following specific economically advantageous management decisions.

\section{Conclusion}

One of the independent types of economic activity of commercial organizations is their investment activity. It provides for the practical implementation of investments. Of particular 
importance to the economy of our country are investment projects in the digital economy. In the process of this activity, the search for the necessary investment resources, the selection of effective investment objects, the formation and implementation of investment projects to achieve the main objectives of the investment strategy of a commercial organization are accomplished [16].

Information about investment activity is formed in the system of financial and management accounting. Financial accounting indicators are reflected in the financial statements, combining data on the implementation of specific investment projects and the investment strategy in general. These statements are the basis for the audit of investment projects. The purpose of the audit of investment projects is to determine whether the commercial organization applies the accounting and taxation procedures for investment accounting to legal acts in force in the Republic of Kazakhstan in the audited period in order to form an opinion on the accuracy of the financial statements in all the audited prerequisites for its preparation [17].

In conclusion, we can draw the following conclusions: firstly, the industrial - innovative modernization of the economy of Kazakhstan requires the development of new measures to solve the key problems of evaluating the results of investment projects. Secondly, the use of audit is only one of the ways to solve, but the most effective, because by its very nature an audit is aimed not only at informing users about financial position, but also at preventing negative consequences of financial and economic activities of organizations, including investment operations. Thus, the successful completion of investment projects is possible only with continuous monitoring of their implementation.

\section{References}

1. T.N. Yudina, Theoretical Economics, 3 (33), 13 (2016)

2. K.K. Arabjan, Organization and conduct of audit (Juniti-Dana, 2010)

3. A.D. Sheremet, V.P. Sujc, Audit (INFRA-M, 2006)

4. D. Dayananda, R. Irons, S. Harrison, J. Herbohn \& P. Rowland, Capital budgeting: financial appraisal of investment projects (Cambridge University Press, 2002)

5. F. Yerdavletova, F.Information technology in the accounting, Advanced Science Letters, Vol 21, N10, 2015, pp. 3305-3307

6. O. Karbanovich, Accountant file, 24, (2013)

7. Azzone, G., \& Maccarrone, P. European Journal of Innovation Management, 4 (2), 73 87 (2001)

8. D.O. Ablenov, Audit Basics (Folio, 2008)

9. S. Richardson, Review of accounting studies, 11(2-3), 159-189 (2006)

10. S.A. Zarevskij, Accounting and statistics, 175-179 (2007)

11. E.V. Nikiforova, O.V. Vector Science of Togliatti State University, 217-219 (2013)

12. F. Fabocci, Investment management (INFRA-M, 2000)

13. V.P. Savchuk, Enterprise Finance Management (Binomial. Knowledge lab, 2005)

14. P.L. Vilenskij, V.N. Livshic, S.A. Smoljak, Assessment of the effectiveness of investment projects (Delo, 2002)

15. USAID, Audit (Enterprise development project, 2003)

16. A. Arene, Dzh. Lobbek, Audit (Finance and statistics, 2001)

17. A. Bexultanov, R. Dulambaeva, S. Ziyadin, Public Administration Issues, 2018(4), 94119 (2018).

18. Ziyadin, S., Ermekbaeva, B., Supugaliyeva, G., Doszhan, R. Proceedings of the 31 st International Business Information Management Association Conference, IBIMA (2018) 